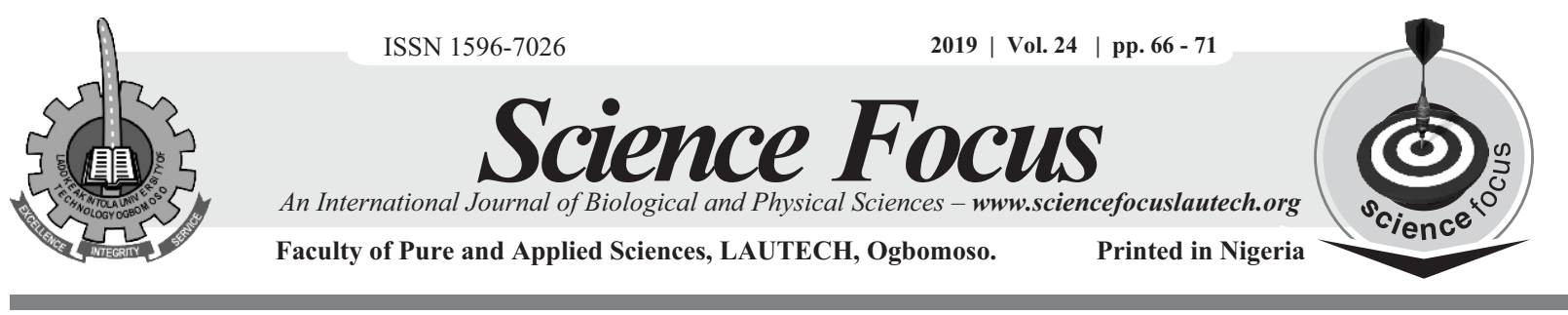

https://doi.org/10.36293/sfj.2019.0046

\title{
ANTIMICROBIAL SPECTRUM OF BRYOPHYLLUM PINNATUM EXTRACT (LEAF) ON SOME CLINICAL BETA-LACTAM RESISTANT TEST ORGANISMS
}

\section{ZAKARI ADEIZA DAVID ${ }^{1 *}$, BELLO KIZITO ENEYE ${ }^{1}$, YUSUF LAMIDI ${ }^{1}$, ADEJOH PATIENCE OMEBIJE ${ }^{1}$, MUSA OIZA AISHA ${ }^{1}$, OLAITAN CATHERINE OHUNENE1, OSAZUWA CHRISTOPHER OLOJEMARIN², OLUMIDE OLUYELE ${ }^{2}$}

\author{
${ }^{1}$ Microbiology Department, Faculty of Natural Sciences, Kogi State University, Anyigba. \\ P.M.B 1008, Anyigba, Kogi State, Nigeria. \\ ${ }^{2}$ Department of Microbiology, Faculty of Life Sciences, Adekunle Ajasin University, Akungba \\ PMB 001,Akoko, Ondo State
}

\begin{abstract}
The trend of emerging drug resistant clinical pathogens are on the rise, therefore it is imperative that newer sources of potent antibiotics be explored. Plants offer a vast array of opportunities. This study examined the antimicrobial activity of both the ethanolic and aqueous extracts of Bryophyllum pinnatum. The clean dry leaves were macerated and various concentrate of the extract was prepared and screened for their antimicrobial activities against selected Beta lactam drug resistant organisms; Methicilin Resistant Escherichia coli, Methicillin Resistant Staphylococcus aureus, Oxacillin Resistant Pseudomonas aeruginosa and Cefoxicin Resistant Candida albicans, via the disc diffusion method, Ciprofloxacin was used as control antibiotic. The Minimum Inhibitory Concentration and Minimum Lethal Concentration of the extracts was determined via the broth dilution method at concentrations ranging from $1.0 \mathrm{~g} / \mathrm{ml}, 0.5 \mathrm{~g} / \mathrm{ml}, 0.25 \mathrm{~g} / \mathrm{ml}, 0.125 \mathrm{~g} / \mathrm{ml}$ for $100 \%, 50 \%, 25 \%$ and $12.5 \% \mathrm{vol} / \mathrm{vol}$ respectively. The ethanolic extract was the most reactive while the aqueous extract showed lesser antimicrobial activity. Methicilin Resistant Eschericha coli have the highest susceptibility to both ethanolic and aqueous extract with a zone of inhibition of $22 \mathrm{~mm}$ and $11 \mathrm{~mm}$ respectively at $p p \leq 0.05$. There was no statistical difference in the concentration and the zone of inhibition as the concentration decreases. Bryophyllum pinnatum possesses pharmacological potentials worthy of exploration to curb the menace of microbial drug resistance.
\end{abstract}

Keywords: B.pinnatum, E.coli, S.aureus, P.aeuginosa, C.albicans, Minimum Inhibitory Concentration) and Minimum Lethal Concentration.

Corresponding Author Email: David.z@ksu.edu.ng

\section{Introduction}

Over the last decade, new emerging and reemerging antibiotic resistant bacteria strain have become a day to day problem for clinicians and researchers (Alam et al., 2016), the need for a more potent, cost effective and efficient solution to this emerging hitch in medicine requires 
strange and new approaches. The latter stirs the need to consider plants and it varying body parts as potential antimicrobial agent to tame the highly emerging bacteria drug resistance (Nascimento et al., 2014).

A substance is said to be antimicrobial if it posses the inherent ability to impede the multiplication and proliferation of a microorganism and plant represent over $70 \%$ of all known sources of potent antibiotic bioactive agents (Kingston, 2014).

Bryophyllum, commonly known as Sprouting leaf is usually found growing in various climatic belts and regions across the tropical rainforest, India China and Northern Australia (Oliver, 2014; Dehbuti et al., 2012). It belongs to the Family CRASSULACEAE. The medicinal importance of the plant is enormous ranging from it application in severe disease treatments and therapy and as an important source of novel bioactive substances that are now use in modern oncological treatments, hence its name; Life plant (Gill, 2012). Bryophyllum pinnatum is usually called several names among the over 100 languages within Nigeria, but basically it is known as "oduaopua" in Igbo land (Igoli et al., 2015), where it grows freely as a perennial herb or planted as ornamentals in individuals households or gardens.

To the best of our knowledge, this study reports the first antibiotic activity of the leaf extract of Bryophyllum pinnatum on Beta Lactamase producing bacteria that are of clinical significance. There is dearth information on the antimicrobial activity of Bryophyllum pinnatum extracts on Methicilin and Oxacillin resisitant bacteria within the study population (Igoli et al., 2015).

\section{Materials and Method of Study}

All the glassware required for this experiment was properly washed with common brand detergent and rinsed with clean sterile distilled water after which they were sterilized at $160^{\circ} \mathrm{C}$ for 2 hours in hot air oven while adhering strictly to established standard guidelines for dry air sterilization in an oven.

The working bench surfaces were disinfected before carrying out any experiment to avoid contamination and to ensure aseptic working conditions.

\subsection{Collection and identification of plant}

The plant and leaves were collected from plant garden in Kogi State University, Anyigba and was identified in the Botanical lab of Plant science department of Kogi State University as Bryophyllum pinnatum using established standard keys as described by Chinaza and Chinweizu (2019).

\section{Preparation of Bryophyllum pinnatum extracts}

Collected Bryophyllum pinnatum leaves were washed shredded and pounded using mortar and pestle. Cold extraction method was implemented. Two sets of $400 \mathrm{~g}$ of the crushed leaves were measured. Each set of the crushed leaves was soaked in $800 \mathrm{ml}$ of ethanol and $800 \mathrm{ml}$ distilled water in two $1000 \mathrm{ml}$ capacity flasks respectively. The flasks were then left standing on a bench with occasional shaking for 72 hours. The extracts were filtered with muslin filter and evaporated to dryness by gentle heating at $70^{\circ} \mathrm{c}$ on a hot plate. The dried concentrates (ethanol and aqueous extracts) were weighed and stored in a desiccator for antimicrobial assay on the isolates.

\section{Preparation of medium}

Nutrient agar, nutrient broth, and peptone water were prepared and sterilized according to the manufacturer's specifications.

\section{Preparation of plant extract concentration}

Different concentration $(\mathrm{v} / \mathrm{v})$ of the extract of Bryophyllum Pinnatum was prepared. For antimicrobial screening; A 1.0 gram (g) of extract were dissolved each in 1 milliliter ( $\mathrm{ml}), 2$ $\mathrm{ml}, 4 \mathrm{ml}$ and $8 \mathrm{ml}$ of distilled water giving concentrations of 1.0 gram-per-milliliter $(\mathrm{g} / \mathrm{ml})$, $0.5 \mathrm{~g} / \mathrm{ml}$ and $0.25 \mathrm{~g} / \mathrm{ml}, 0.125 \mathrm{~g} / \mathrm{ml}$ at $100 \%$, $50 \%, 25 \%$ and $12.5 \%$, respectively. The Minimum Inhibitory Concentration (MIC) was determined from the $1.0 \mathrm{~g} / \mathrm{ml}, 0.5 \mathrm{~g} / \mathrm{ml}, 0.25$ $\mathrm{g} / \mathrm{ml}$ and $0.125 \mathrm{~g} / \mathrm{ml}$ concentrations, as a $0.2 \mathrm{ml}$ of extract was dispensed into three different broth tubes containing the various test organisms. 


\section{Antimicrobial evaluation}

Antimicrobial Evaluation on each of the different concentration of the Bryophyllum pinnatum was done using Kirby-Bauer diffusion susceptibility test method (also called the disc diffusion test). Discs (3mm) were obtained by perforating filter paper. The discs were sterilized using oven and impregnated with known concentrations of plant extracts then allowed to dry. Nutrient agar and peptone water was prepared following manufacturer's instruction, autoclaved at $15 \mathrm{psi}$ for 15 minutes, allowed to cool then poured in the petri-dishes and were left to set under aseptic environment, a pure cultures of Methicillin resistant Escherichia coli, Oxacillin resisitant Pseudomonas aeruginosa, Methicillin Resistant Staphylococcus aureus, and cefoxitin resistant Candida albicans inoculums adjusted to $0.5 \mathrm{McF}$ arland's standard was well seeded on the surface of the agar plate with a sterile swab stick via the spread plate inoculating method. Impregnated discs and antibiotic disc (Ciprofloxacin which served as control) were placed on plates using sterile forceps. The resulting culture was incubated at $37^{\circ} \mathrm{C}$ for $24 \mathrm{hrs}$ for the bacteria test organisms and $72 \mathrm{hrs}$ for the fungal test organism. The zone of inhibition was measured in millimeters and was recorded appropriately.

The MICs were determined using broth dilution technique. About $3 \mathrm{ml}$ of the nutrient broth and peptone water were introduced into test tubes. Approximately $0.2 \mathrm{ml}$ of the extract at different concentrations was introduced into each of the test tubes. The test organisms (20ul) were inoculated into the tubes and then incubated at $37^{\circ} \mathrm{C}$ for 24 hours and $72 \mathrm{hrs}$ after which the Minimum Inhibitory Concentration was observed as the least concentration of extract which resulted in no visible growth and was thus recorded. The Minimum Lethal Concentration (MLC) was determined by sub culturing the MIC assay hat did not indicate any growth after incubation for 24 hours and 72 hours. The latter was carried out by sub-culturing inoculums from MIC positive cultures into sensitivity test agar dish, incubated for 24 hours and 72 hours. The highest dilution of the concentration that yielded no single bacterial colony was taken as the Minimum bactericidal Concentration as described by Akinyemi et al., (2005). The MLCs were obtained when broth tubes containing no visible growth were sub cultured unto a solid media without any antimicrobial agent and no colonies were formed.

\section{Results and Discussion}

This study shows that the antimicrobial activities of the ethanolic extracts of Bryophyllum pinnatum leaves against the test organisms were the most reactive at all concentrations. The zones of inhibition of the extracts also showed that Methicillin Resistant Escherichia coli was the most susceptible organism to both ethanolic and aqueous extract with the highest zone of inhibition $(22 \mathrm{~mm}$ for ethanolic extract and $13 \mathrm{~mm}$ for aqueous extract respectively). Cefoxitin Resistant Candida albican was the least susceptible in both ethanolic and aqueous extract of the tested plant leave $(12 \mathrm{~mm}$ for ethanolic extract and $11 \mathrm{~mm}$ for aqueous extract respectively) as shown in Table 1 and Table 2.

At concentration of $25 \%(0.25 \mathrm{~g} / \mathrm{ml})$, Methicillin Resistant Escherichia coli and Oxacillin Resistant Pseudomonas aeruginosa did not show any sign of growth (clear) thus was taken as the MIC, while Methicillin Staphylococcus aureus and Cefoxitin Candida albicans 50\% $(0.5 \mathrm{~g} / \mathrm{ml})$ was taken as the MIC as shown in Table 3. Methicillin Resistant Escherichia coli and Oxacillin Resistant Pseudomonas aeruginosa had MLC at $25 \% \quad(0.25 \mathrm{~g} / \mathrm{ml})$, Methicillin Staphylococcus aureus and Cefoxitin Candida albicans had MLC at $50 \%(0.5 \mathrm{~g} / \mathrm{ml})$ as shown in Table 3. 
Table 1: Antimicrobial activity of ethanolic extract of Bryophyllum pinnatum

\begin{tabular}{|c|c|c|c|c|c|}
\hline \multirow[t]{3}{*}{ Test Organisms } & \multicolumn{4}{|c|}{ Zone of inhibition } & \multirow{3}{*}{$\begin{array}{l}\text { Antibiotic } \\
\text { Control } \\
(10 \mu \mathrm{g} / \mathrm{ml})\end{array}$} \\
\hline & \multicolumn{4}{|c|}{ (Concentration in \%) } & \\
\hline & 100 & 50 & 25 & 12.5 & \\
\hline $\begin{array}{l}\text { Methicilin Resistant } \\
\text { Escherichia coli }\end{array}$ & $22 \mathrm{~mm}$ & $13 \mathrm{~mm}$ & $9 \mathrm{~mm}$ & $6 \mathrm{~mm}$ & $20 \mathrm{~mm}$ \\
\hline $\begin{array}{l}\text { Methicilin Resistant } \\
\text { Staphylococcus aureus }\end{array}$ & $14 \mathrm{~mm}$ & $12 \mathrm{~mm}$ & $5 \mathrm{~mm}$ & Nil & $18 \mathrm{~mm}$ \\
\hline $\begin{array}{l}\text { Oxacillin Resistant } \\
\text { Pseudomonas } \\
\text { aeruginosa }\end{array}$ & $19 \mathrm{~mm}$ & $17 \mathrm{~mm}$ & $10 \mathrm{~mm}$ & $8 \mathrm{~mm}$ & $31 \mathrm{~mm}$ \\
\hline $\begin{array}{l}\text { Cefoxitin Resistant } \\
\text { Candida albicans }\end{array}$ & $12 \mathrm{~mm}$ & $7 \mathrm{~mm}$ & Nil & Nil & $15 \mathrm{~mm}$ \\
\hline
\end{tabular}

Table 2: Antimicrobial activity of aqueous extract of Bryophyllum pinnatum

\begin{tabular}{|c|c|c|c|c|c|}
\hline \multirow[t]{2}{*}{ Test Organisms } & \multicolumn{4}{|c|}{$\begin{array}{l}\text { Zone of inhibition } \\
\text { (Concentration in \%) }\end{array}$} & \multirow{2}{*}{$\begin{array}{l}\text { Antibiotic } \\
\text { Control } \\
(10 \mu \mathrm{g} / \mathrm{ml})\end{array}$} \\
\hline & 100 & 50 & 25 & 12.5 & \\
\hline $\begin{array}{l}\text { Methicilin Resistant } \\
\text { Escherichia coli }\end{array}$ & $13 \mathrm{~mm}$ & $8 \mathrm{~mm}$ & Nil & Nil & $11 \mathrm{~mm}$ \\
\hline $\begin{array}{l}\text { Methicilin Resistant } \\
\text { Staphylococcus aureus }\end{array}$ & $11 \mathrm{~mm}$ & $7 \mathrm{~mm}$ & $9 \mathrm{~mm}$ & Nil & $16 \mathrm{~mm}$ \\
\hline $\begin{array}{l}\text { Oxacillin Resistant } \\
\text { Pseudomonas } \\
\text { aeruginosa }\end{array}$ & $11 \mathrm{~mm}$ & $9 \mathrm{~mm}$ & $5 \mathrm{~mm}$ & Nil & $10 \mathrm{~mm}$ \\
\hline $\begin{array}{l}\text { Cefoxitin Resistant } \\
\text { Candida albicans }\end{array}$ & $8 \mathrm{~mm}$ & $5 \mathrm{~mm}$ & Nil & Nil & $12 \mathrm{~mm}$ \\
\hline
\end{tabular}

Table 3: Minimum inhibitory concentration of ethanolic leaf extracts and aqueous extracts of Bryophyllum pinnatum

Key; $\mathrm{NG}=\mathrm{NO}$ growth, $\mathrm{G}=$ growth

\begin{tabular}{lllllllll}
\hline Test Organisms & \multicolumn{4}{c}{ Ethanol leaf extract (\%) } & \multicolumn{3}{c}{ Aqueous leaf extract (\%) } \\
& 100 & 50 & 25 & 12.5 & 100 & 50 & 25 & 12.5 \\
\hline Escherichia coli & NG & NG & NG & G & NG & G & G & G \\
Staphylococcus aureus & NG & NG & G & G & NG & G & G & G \\
$\begin{array}{l}\text { Pseudomonas } \\
\begin{array}{l}\text { aeruginosa } \\
\text { Candida albicans }\end{array}\end{array}$ & NG & NG & NG & G & NG & G & G & G \\
\hline
\end{tabular}


Table 4: Minimum lethal concentration of ethanolic bryophyllum pinnatum

\begin{tabular}{llll}
\hline Test Organisms & \multicolumn{3}{c}{ Ethanol leaf extract (\%) } \\
& 50 & 25 & 12.5 \\
\hline $\begin{array}{l}\text { Methicilin Resistant } \\
\begin{array}{l}\text { Escherichia coli } \\
\text { Methicilin Resistant }\end{array}\end{array}$ & $\mathrm{NG}$ & $\mathrm{NG}$ & $\mathrm{G}$ \\
$\begin{array}{l}\text { Staphylococcus aureus } \\
\text { Oxacillin Resistant }\end{array}$ & $\mathrm{NG}$ & $\mathrm{G}$ & $\mathrm{G}$ \\
$\begin{array}{l}\text { Pseudomonas aeruginosa } \\
\text { Cefoxitin Resistant } \\
\text { Candida albicans }\end{array}$ & $\mathrm{NG}$ & $\mathrm{NG}$ & $\mathrm{G}$ \\
\hline
\end{tabular}

Key; $\mathrm{NG}=\mathrm{NO}$ growth, $\mathrm{G}=$ growth

Methicilin resistant Escherichia coli and Oxicallin Resistant Pseudomonas aeruginosa had MLC at 25\% $(0.25 \mathrm{~g} / \mathrm{ml})$, while Staphylococcus aureus and Candida albicans had MLC at 50\% (0.5g/ml).

The ethanol extract of the leaves was the most potent showing antimicrobial activity on one or all of the test organisms at low to higher concentrations $(0.125-1.0 \mathrm{~g} / \mathrm{ml})$, the probable reason for this is unclear but it could be due to established knowledge that ethanol is an efficient extraction solvent either due to it polarity or concentration. Aquil and Ahmad (2013) reported that phytochemicals have a high dissolution index in solvent with high polarity. The latter can be attributed to the reason for the high efficacy of the ethanolic extract of Bryophyllum pinnatum. This study is in agreement with the findings of Aquil and Ahmad (2013) where they reported that the ethanolic extract of Bryophyllum pinnatum has a broad spectrum activity against bacteria and fungi. The aqueous extract of Bryophyllum pinnatum showed moderate antimicrobial activity. The latter is in agreement with the independent reports of Ofokansi (2015) and Akinpelu (2000).

The extracts were effective on Gram positive, Gram negative bacteria and a fungus. Methicillin Resistant Escherichia coli showed significant susceptibility at all concentrations of the ethanol extract with inhibition values ranging from 6$22 \mathrm{~mm}$. In contrast to the commonly reported resistance of Gram negative bacteria to antimicrobial agents, the extracts showed better activity against them than the Gram positive bacterium used. The latter is in agreement with Akinpelu (2000). The MIC of the ethanolic extract for Methicillin Resistant Escherichia coli and Oxacillin Resistant Pseudomonas aeruginosa is taken at $25 \%(0.25 \mathrm{~g} / \mathrm{ml})$ while for Methicillin Resistant Staphylococcus aureus and
Cefoxitin Resistant Candida albicans 50\% $(0.5 \mathrm{~g} / \mathrm{ml})$ was taken as the MIC, the low concentrate Minimal inhibition is a strong indication that the extract is a high reference candidate in the quest for new effective antibiotic discovery from plants, this is also in strong agreement with the reports of CDC (2014), where they reported that plants offers a vast opportunities for novel bioactive compound discovery against drug resistant microrganisms.

Methicillin Resistant Escherichia coli and Cefoxitin Resistant Candida albicans have the highest and lowest inhibition respectively. The ethanol extract showed lethal effects on Methicillin Resistant Escherichia coli and Oxacillin Resistant Pseudomonas aeruginosa at concentration of $25 \% \quad(0.25 \mathrm{~g} / \mathrm{ml}) \quad$ while Methicillin Resistant Staphylococcus aureus and Cefoxitin Resistant Candida albicans at concentration of $50 \%(0.5 \mathrm{~g} / \mathrm{ml})$.

\section{Conclusions}

The heavy burden of antimicrobial drug resistant on researchers and clinicians have increased the need for the discovery of novel bioactive agents from natural sources to which plant stands as king. Our study shows that extracts of Bryophyllum pinnatum have moderate to high antibiotic activity on the tested organisms and its MIC and MLC values are acceptable. Therefore more findings should be made on the bioactive constituents of Bryophyllum pinnatum as it demonstrates dynamic pharmacological potentials. 


\section{References}

Akinpelu, D.A. (2000). Antimicrobial activity of Bryophyllumpinnatum leaves. Fitoterapia 71: 193-194.

Alam, M.T., Karim, M. M. and khan, S. N. (2016).Antibacterial activity of different organic extracts of Achyranthesaspera and cassia alata. Journal of Science Research. 1: 381-393.

Aquil, F. and Ahmad, I. (2013). Broad-spectrum antibacterial and antifungal properties of certaintraditionally used Indian medicinal plants. World Journal Microbiology. Biotechnology. 19: 653-657.

Centre for Disease and Control (CDC) (2014). Risk assessment on the spread of carbapenemase-producing Enterobacteriaceae. 18: $53-57$

Chinaza, O and Chinweizu, OU (2019). Antibacteria effect of methanolic extract of Bryophyllum pinnatum L on Methicillin Resistant Stapylococcus aureus (MRSA) isolated from urine. Journal of Advances in Microbiology: 9: pp 241-49

Devbhuti, D., Gupta, K.K and Devbhuti, P. (2012). Studies on Antitumour activity of Bryophyllum calycinumsalish against ehrilichascites carcinoma in swiss albino mice. Journal of Pharmaceutical Science and Technology 2(1): 31-33.
Gill, L.S. (2012).Ethno-medical uses of plant in Nigeria UNIBEN Press.46

Igoli, J.O; Ogaji, O.G; Toranyiin, A.T. and Igoli, N.P. (2015).Traditional medicine practice amongst the Igede people of Nigerian part II.African Journal of Tradition Complementary and Alternation Medicines.2(2): 134-152.

Kingson, W. (2014). "Irish Contribution to the origin of antibiotics". Irish Journal of Medical Sciences. 177(2): 87-92.

Nascimento, G.F.; Locatelli, J.; Freitas, P.C. and Silvia, G.L (2014).Antibacterial activity of plant extracts and phytochemicals on antibiotics resistant bacterial.Brazilian Journal of Microbiology. 31: 247-256.

Ofokansi, K.C.; Esimone, C.O and Anele, C.R. (2015).Plant Products Research Journals. 9: 2327.

Oliver, B. (2014). Medicinal plants in tropical west Africa III. Anti-infection therapy with higher plants.Journal of Ethnopharmacology. 9: $1-83$

World Health Organization (WHO).(2017). Resolution-Promoting and development of training and research in traditional medicine. WHO document 30: 49-50. 